\title{
HEBREWS 3:6B AND 3:14 REVISITED
}

\author{
Andrew J. Wilson
}

\begin{abstract}
Summary
Hebrews 3:6b and 3:14 have been central to Reformed interpretations of the warnings in Hebrews for several centuries. Today, however, there is something of an impasse in scholarship: on one side, there are those who see these verses as an interpretive key to the letter, and thus understand the warnings to refer to spurious or false believers; on the other, there are those who argue that since Hebrews warns real believers away from real apostasy, these two verses cannot mean what, at a grammatical level, they appear to mean. In this paper, I appraise the scholarly discussion so far, identify three key issues relating to grammar and context, and then propose a way through the impasse that has not been considered in modern scholarship.
\end{abstract}

\section{Introduction}

The warning passages in Hebrews have attracted a great deal of attention through church history. ${ }^{1}$ They have drawn the attention of exegetes and commentators, who rightly perceive these strong admonitions as being at the heart of the letter's purpose. New Testament theologians have often reflected on their apparent difference of perspective from that of Paul, and wondered aloud whether reconciliation is possible, or indeed desirable. They have produced more than their fair share of systematic-theological controversy, as one of the chief battlegrounds for Calvinist and Arminian systems on the question of perseverance in salvation. And of course pastors, with churches and individuals in mind, have wrestled with them across the

1 For the purposes of this study, the warnings will be identified as $2: 1-4 ; 3: 7-4: 13$; 5:11-6:8; 10:26-31; 12:1-29, following Scot McKnight, 'The Warning Passages of Hebrews: A Formal Analysis and Theological Conclusions', TrinJ 13 (1992): 21-59. 
centuries, as they have attempted to apply them to the lives of their contemporaries.

All this attention has produced a large number of different ways of handling the warnings; to date, at least eighteen distinct interpretations of Hebrews 6:4-6 alone have been proposed. ${ }^{2}$ But within contemporary scholarship, two views predominate. The mainstream view, shared by the majority of critical scholars and a number of others, is that the author believes Christian believers can apostasise and forfeit eternal salvation, and that he is warning them against doing so in the strongest possible terms. The largest minority view, which tends to be held by scholars from a more Reformed background, is that the warnings refer instead to 'professors not possessors': people in the church community who appear to be true believers but whose conduct, in the end, may prove that they are not. From time to time, there are occasional arguments in the literature for alternative readings of the warnings, but almost every commentary to have appeared in the last few decades has followed one of these two lines of interpretation.

Two verses which are often brought into the discussion, particularly by more Reformed writers, and which are long overdue a reappraisal in the light of current scholarship and grammatical considerations, are the two parallel sentences in chapter 3 , verses $6 \mathrm{~b}$ and 14 :

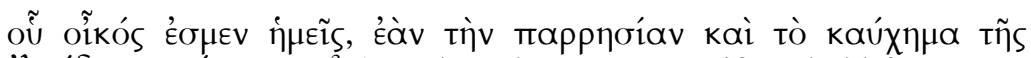
$\dot{\varepsilon} \lambda \pi \hat{i} \delta$ os $k \alpha T \alpha ́ \sigma \chi \omega \mu \varepsilon v^{3}$ (... whose house we are, if we hold fast to our confidence and our boasting in hope.)

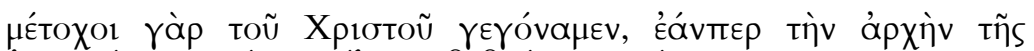

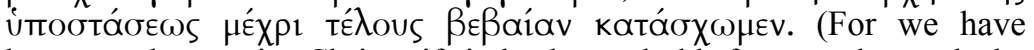
become sharers in Christ, if indeed we hold fast to the end the confidence we had at first.)

The reason these verses are so significant, particularly with respect to the warning passages in Hebrews taken together, is that they appear to make the present experience of being 'his house' (3:6b), and in fact the past experience of having become 'sharers in Christ' (3:14), dependent upon a future condition: that of holding fast one's confidence, one's

2 R. Sauer, A Theological and Exegetical Re-examination of Hebrews 5:11-6:8, unpublished $\mathrm{PhD}$ dissertation (Manchester, 1981), finds fifteen interpretations of 6:4-6, and Michael Eaton, A Theology of Encouragement (Carlisle: Paternoster, 1995), notes sixteen, but each omits a number of the other's.

3 The additions represented in the Textus Receptus are generally acknowledged to be attempts to conform 3:6b to 3:14; we have followed Westcott-Hort here. 
boasting in hope, until the end. Thus, for example, the translation of 3:14 in the REB:

We have become partakers with Christ, if only we keep our initial confidence firm to the end.

What could this possibly mean? The spectrum of scholarly opinion ranges from those who see this translation as 'unnecessarily difficult' because it 'appears to make a past condition dependent on a future', through to those who argue that this is precisely the writer's intention, and that these verses are in fact an 'interpretive paradigm' for the warnings as a whole. ${ }^{4}$ The former, which we will here refer to as the mainstream view, would tend to see 3:6b and 3:14 as simply different ways of stating what Hebrews says repeatedly: perseverance in faith is vital to inherit future salvation. The latter, more typically Reformed, view is that this is not what 3:6b and 3:14 are saying; rather, it is said, they show that those who persevere in faith are the ones who have truly become 'partakers in Christ' and 'his house'. Clearly, the discussion is of some importance for the interpretation of the warnings in Hebrews, because in the mainstream view, Hebrews teaches that true believers can forfeit eschatological salvation, and in the Reformed view, Hebrews teaches that true believers will not. In this paper, we will review the scholarly discussion thus far, engage with the primary issues, and consider a possible way forward which, to our knowledge, has not been considered in the existing scholarly literature.

\section{The Discussion so Far}

The majority view amongst critical scholars has long been that Hebrews $3: 6 \mathrm{~b}$ and 14 express the importance of perseverance by explaining that remaining a partner with Christ is impossible without it.

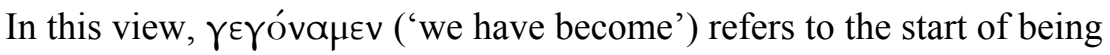
a partner with Christ, but holding fast one's confidence is necessary to maintain it; as Paul Ellingworth summarises, 'We have become, and are now, partners with Christ; and we shall remain such if we hold fast

4 For the former, see Paul Ellingworth, The Epistle to the Hebrews (NIGTC; Grand Rapids: Eerdmans, 1993): 227; for the latter, see Buist Fanning, 'A Classical Reformed View' in Four Views on the Warning Passages in Hebrews, ed. Herbert Bateman IV (Grand Rapids: Kregel, 2007): 206-207. 
to the end. ${ }^{5}$ This, generally speaking, would be the interpretation stated or assumed by most major commentators in the last half century, including Spicq, Montefiore, Michel, Braun, Attridge, Lane, Weiss, Ellingworth, Grässer, deSilva and Koester. ${ }^{6}$

The Reformed interpretation of Hebrews 3:6b and 3:14 is somewhat different, and was most influentially formulated by the Puritan John Owen. He argued that these verses meant that

our subsistence in Christ is twofold, either by profession only, or by real union; and the trial of which it is of these we are partakers of depends on our perseverance ... Constancy and steadfastness in believing is the great touchstone, trial, and evidence of union with Christ. ${ }^{7}$

In other words, for Owen, the meaning of these verses is that perseverance demonstrates one's union with Christ. In recent scholarship, this type of interpretation has been expressed most clearly and coherently by F. F. Bruce, who comments on 3:6b:

Nowhere in the New Testament more than here do we find such repeated insistence on the fact that continuance in the Christian life is the test of reality. The doctrine of the final perseverance of the saints has as its corollary the salutary teaching that the saints are the people who persevere to the end. ${ }^{8}$

In this interpretation, the writer to the Hebrews has deliberately made a past event dependent on a future condition, because perseverance in faith is a defining mark of those who are truly believers. Although this remains a minority position within scholarship, it is certainly the most common alternative reading of the passage, and represents the view of

5 Ellingworth, Hebrews, 227.

6 Céslas Spicq, L'Épître aux Hébreux (2 vols.; Paris: Gabalda, 1952): 2:77; Hugh Montefiore, The Epistle to the Hebrews (London: A\&C Black, 1964): 78-79; Otto Michel, Der Brief an die Hebräer (Göttingen: Vandenhoeck \& Ruprecht, 1966); Herbert Braun, An die Hebräer (HNT 14; Tübingen: Mohr, 1984); Harold Attridge, The Epistle to the Hebrews (Hermeneia; Philadelphia: Fortress, 1989): 117-19; William Lane, Hebrews (WBC; 2 vols.; Dallas: Word Books, 1991): 87-88; HansFriedrich Weiss, Der Brief an die Hebräer (Göttingen: Vandenhoeck \& Ruprecht, 1991): 250; Ellingworth, Hebrews, 227; Erich Grässer, An die Hebräer (EKK 17; 3 vols.; Zurich: Benzinger, 1990-7); David deSilva, Perseverance in Gratitude: A Socio-Rhetorical Commentary on the Epistle 'to the Hebrews' (Grand Rapids: Eerdmans, 2000): 139-40, 150-51; Craig Koester, Hebrews: A New Translation with Introduction and Commentary (Anchor; New Haven: Yale, 2001).

7 John Owen, Epistle to the Hebrews (Grand Rapids: Kregel, 1968): 57.

8 F. F. Bruce, The Epistle to the Hebrews (NICNT; Grand Rapids: Eerdmans, 1990): 94. 
several major commentators, including Hughes, Guthrie and O'Brien, as well as Bruce. ${ }^{9}$

Perhaps surprisingly, given how pivotal it is for the most widely held alternative view of the warnings in Hebrews, many critical commentaries do not engage with this line of interpretation at all. The comments on 3:6b and 14 by Attridge, Lane, Ellingworth, deSilva and Koester, for example, have just five sentences and one footnote between them which respond to the interpretation of these verses presented by Bruce and others, and only one of them even mentions the grammatical construction which appears to make a past reality dependent upon a future condition. ${ }^{10}$ In other words, though many commentators would agree on the majority view, very few would provide any substantiation for it in their commentaries. Consequently, the bulk of the discussion has taken place within articles which address the subject in more detail. Of these, the most significant are probably those of Carson and Fanning (who argue for the Reformed interpretation of 3:6b and 14) and McKnight, Schreiner and Caneday, and Osborne (who prefer the majority view). It remains to consider each of them briefly.

D. A. Carson has argued in two of his works, responding specifically to Howard Marshall, that Hebrews 3:14 indicates that 'although perseverance is mandated, it is also the evidence of what has

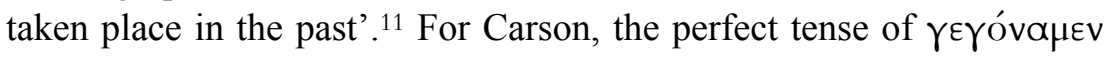
is crucial, for it indicates a past reference: we have become partakers of Christ in the past if we hold firmly to our confidence in the present. As such, he says, 'if persevering shows we have (already) come to share in Christ, it can only be because sharing in Christ has perseverance for its inevitable fruit', a conclusion which he elsewhere states even more directly: 'Hebrews virtually defines true believers as those who hold firmly to the end the confidence they had at first $(3: 6 b, 14)$. In other

9 P. E. Hughes, A Commentary on the Epistle to the Hebrews (Grand Rapids: Eerdmans, 1977); Bruce, Hebrews, 94; George Guthrie, Hebrews (NIVAC; Grand Rapids: Zondervan, 1998): 130; Peter O'Brien, The Letter to the Hebrews (PNTC; Grand Rapids: Eerdmans, 2010): 136, 150-51.

10 That is, Ellingworth, Hebrews, 227 (although even here, no argument is made in response, and the REB translation cited earlier is simply dismissed as 'unnecessarily difficult'); for the footnote, see deSilva, Hebrews, $140 \mathrm{n}$. 13, responding to Stedman.

11 D. A. Carson, Exegetical Fallacies (Grand Rapids: Baker, 1996): 85, responding to Howard Marshall, Kept by the Power of God: A Study of Perseverance and Falling Away (London: Paternoster, 1995). 
words, like other New Testament books the Epistle to the Hebrews allows for a kind of transitory faith, a form of conversion which, like the seed sown on rocky soil, has all the signs of life, but which does not persevere.' ${ }^{12}$ This position lines up more or less exactly with that of John Owen and F. F. Bruce, as we have seen.

Scot McKnight, in a clear and oft cited analysis of the warnings in Hebrews, responded to this position in three main ways. ${ }^{13}$ Firstly, and in the most detail, he analysed the warnings collectively, and argued that they were addressed to true Christian believers, not (as Bruce and others would say) to those who appeared to be believers but were not. ${ }^{14}$

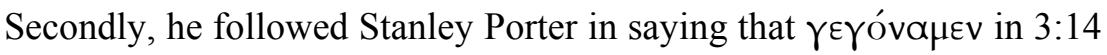
was a 'timeless' perfect, and therefore that it did not imply that the event was necessarily a past reality, so Carson's main argument, based on the perfect tense, was flawed. ${ }^{15}$ Thirdly, he stressed the futurity of final salvation and the contingency of receiving it upon perseverance, concluding:

Even if the grammar of 3:6b, 14 is difficult, here again the futurity of full salvation is clear ... In these two conditional expressions we have a contingent element ('sharing in Christ', 'being his house') based upon a persevering faith ('if we hold on to our courage and the hope', 'if we hold firmly till the end the confidence'). Perseverance in faith issues into future, final salvation. In each of these there is a present reality, the continuance of which is dependent upon perseverance. If that person does not persevere, there will be a cessation of that former reality. ${ }^{16}$

This, it will be noted, lines up with the majority view described above, as expressed by Spicq, Weiss, Ellingworth and others.

Thomas Schreiner and Ardel Caneday, like McKnight, respond to Carson's article (once again, it is surprising how rarely F. F. Bruce's

12 Carson, Exegetical Fallacies, 84-85; D. A. Carson, 'Reflections on Assurance' in Still Sovereign, Thomas Schreiner and Bruce Ware (Grand Rapids: Baker, 2000): 267.

13 McKnight, 'Warning Passages'.

14 So Bruce, Hebrews, 144, on 6:4-6: 'In these verses he is not questioning the perseverance of the saints; we might say that rather he is insisting that those who persevere are the true saints.' The bulk of McKnight's entire article is directed to challenging this interpretation, particularly as presented in Roger Nicole, 'Some Comments on Hebrews 6:4-6 and the Doctrine of the Perseverance of God with the Saints' in Current Issues in Biblical and Patristic Interpretation, ed. G. F. Hawthorne (Grand Rapids: Eerdmans, 1975): 355-64.

15 McKnight, 'Warning Passages', 24; cf. Stanley Porter, Verbal Aspect in the Greek of the New Testament, with Reference to Tense and Mood (SBG 1; New York: Peter Lang, 1989): 269.

16 McKnight, 'Warning Passages', 57. 
argument is mentioned in the literature), and also find it inadequate. ${ }^{17}$ They see the parallels between $3: 6 \mathrm{~b}$ and $3: 14$ as indicating that

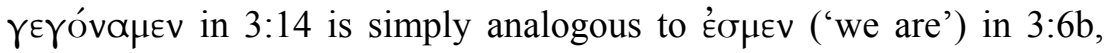
and that it certainly does not mean 'we prove to be sharers in Christ'.

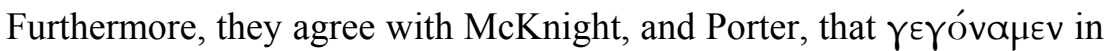
$3: 14$ is a timeless perfect, and therefore that the sense is not 'we have become partakers if we hold fast', but 'we are and will remain partakers if we hold fast'. They also argue that the intensified conditional kávтrep ('if indeed') 'stresses the necessity of fulfilling the supposition in order that the consequent may be realised', which means that the verse has 'a clear future orientation'. ${ }^{18}$ For Schreiner and Caneday, then, it makes no sense to speak, as Carson does, of a past event being dependent on a future condition.

The most detailed study of Hebrews 3:6b and 3:14 undertaken to date, as far as I am aware, is that of Buist Fanning. In his contribution to the multi-author volume Four Views on the Warning Passages in Hebrews, Fanning gives thirteen pages to an analysis of the grammar of $3: 6 \mathrm{~b}$ and $3: 14$, in the course of which he responds to McKnight, Schreiner and Caneday, and others, and argues that these verses are an 'interpretive paradigm' for the warnings as a whole. He summarises his position like this:

Careful attention to the wording shows that these lines do not cite what will be true if they hold on, but what is already true of them, if in fact they endure ... Holding on to their confidence will reveal the reality they already have come to share in Christ, not what they will share. By continuing in faith, they demonstrate the work Christ has already begun and will certainly accomplish in them (as argued above from 7:25; 8:12; $9: 14-15 ; 10: 14){ }^{19}$

Two main grammatical considerations bring him to this conclusion. His first concern is to challenge the assumption that the conditionals in $3: 6 \mathrm{~b}$ and 3:14 are cause-to-effect conditionals, and to show that they are in fact evidence-to-inference conditionals. In other words, Fanning contends, they do not speak of perseverance as a cause and sharing in Christ as an effect (if you persevere, you will continue sharing in Christ), but rather of perseverance as evidence, and sharing in Christ as

17 Thomas Schreiner and Ardel Caneday, The Race Set Before Us: A Biblical Theology of Perseverance and Assurance (Downers Grove: InterVarsity Press, 2001): 200-202.

18 Schreiner and Caneday, Race, 201.

19 Fanning, 'View', 207. 
an inference (if you persevere, then you have come to share in Christ). ${ }^{20}$ His second argument, which supplements this one, is that McKnight, Porter, Schreiner and Caneday are wrong to see the perfect in 3:14 as 'timeless', both because Porter's 'timeless perfect' is questionable in the first place, and because the inversion of the conditional clauses, with the apodosis first, indicates that the normal temporal sense is intended. ${ }^{21}$ These are both complex arguments which need further elaboration below.

In the same volume, Grant Osborne responds directly to Fanning on $3: 6 \mathrm{~b}$ and $3: 14$ with two main challenges.22 Firstly he argues, like McKnight, that the targets of the warnings are genuine Christian believers who are in danger of apostasy, and that this makes Fanning's interpretation of $3: 6 \mathrm{~b}$ and $3: 14$ - that true believers will ultimately persevere - untenable. ${ }^{23}$ Secondly, Osborne finds the evidence-toinference argument unpersuasive, on the grounds that the apodoses in $3: 6 \mathrm{~b}$ and 3:14 do not describe a 'prior condition', but 'partake of the same force as the éáv clauses ('if you hear his voice') of verses 7, $15^{\prime} .{ }^{24}$ For Osborne, it is better to see these verses as cause-to-effect: 'only "if" they persevere will they partake of Christ'. ${ }^{25}$

In the scholarly discussion so far, then, there are three main issues

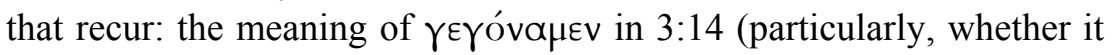
is a 'timeless' perfect), the relationship between the protases and apodoses in both sentences (cause-to-effect or evidence-to-inference), and the wider context of the letter as a whole (that is, whether the warning passages collectively make either interpretation more or less plausible). For the rest of this paper, we will consider these three issues in turn, and propose a way of moving beyond the current impasse, to a fresh understanding of these verses and the warnings in Hebrews as a whole.

\footnotetext{
20 Fanning, 'View', 207-214.

21 Fanning, 'View', 215.

22 Grant Osborne, 'Classical Arminian Response' in Bateman, Four Views, 220-32.

23 Osborne, 'Response', 224-25.

24 Osborne, 'Response', 231.

25 Osborne, 'Response', 231.
} 


\section{The Meaning of $\gamma \varepsilon \gamma o ́ v \alpha \mu \varepsilon v$ in 3:14}

At first glance, the use of $\gamma \varepsilon \gamma$ óva $\mu \varepsilon v$ in Hebrews 3:14 does appear to make a past event ('we have become partners with Christ') dependent on ongoing perseverance ('if we hold fast our confidence to the end'). This is the implication of the majority of English translations:

For we have become partners of Christ, if only we hold our first confidence firm to the end. (NRSV)

For we have come to share in Christ, if indeed we hold our original confidence firm to the end. (ESV)

For we have become partakers of Christ, if we hold fast the beginning of our assurance firm until the end. (NASB)

As we have seen, for interpreters like Bruce, Hughes, Carson, Guthrie and Fanning, this is exactly what the writer means. We have become partners with Christ if only we hold fast to the end - and therefore, because of the intensified conditional ḱóvтrep (which normally means 'if indeed', or more colloquially, 'if and only if'), those who do not hold fast to the end have not become partners in Christ. It is as simple as that.

The main challenge to this view at a grammatical level, as cited both by McKnight and by Schreiner and Caneday, is Stanley Porter's contention that, in using the perfect in 3:14, 'the author draws a timeless conclusion' concerning the readers' partnership with Christ. ${ }^{26}$ For Porter, a grammarian who has specialised in aspect theory, verbs in the indicative mood are not primarily concerned with time (hence his use of the word 'timeless' of 3:14), but with a subjective perspective on an action. ${ }^{27}$ To infer, then, that the apodosis in 3:14 explicitly states the readers' partnership in Christ to have begun in the past is, for Porter, invalid; that is simply not what the perfect tense is all about.

Porter's argument has been subjected to substantial criticism, both at the general and at the specific level. At the general level, Fanning (who was writing his $\mathrm{PhD}$ dissertation on verbal aspect at the same time as Porter) proposes a very different approach to temporality in the indicative mood, and major grammarians like Steven Runge and Daniel Wallace argue that Porter's 'nontemporal' reading of verbs in the

26 Porter, Aspect, esp. 269; this is cited in both McKnight, 'Warning Passages', 24, and Schreiner and Caneday, Race, 201.

27 A helpful summary of his position is given in Stanley Porter, ed., Handbook to Exegesis of the New Testament (Leiden: Brill, 1997): 117. 
indicative mood is highly problematic. ${ }^{28}$ In a careful discussion, Wallace evaluates seven lines of argument on the nontemporal view, and concludes that 'the unaffected meaning of the tenses in the indicative involves both aspect and time', although either can be suppressed in the context. ${ }^{29}$ Furthermore, at the specific level, a number of scholars who share Porter's timeless view of the indicative in general have challenged his implementation of the principle to particular texts, including Hebrews 3:14. ${ }^{30}$ The result is that, of the five most significant New Testament Greek grammars to be published in the last two decades or so (those of Fanning, Porter, McKay, Wallace and Runge), four of them are written by authors who seriously question either Porter's framework, or his application of it to Hebrews 3:14, or both - and the fifth is Porter himself. ${ }^{31}$ None of this means that Porter's view is thereby proven wrong, of course, but it does mean that citing him to dismiss the Reformed view of 3:14 must be regarded as insufficient. ${ }^{32}$

28 Buist Fanning, Verbal Aspect in New Testament Greek (OTM; Oxford: Clarendon Press, 1990); Daniel Wallace, Greek Grammar Beyond the Basics: An Exegetical Syntax of the New Testament (Grand Rapids: Zondervan, 1996): 506-512; cf. also Steven Runge, 'On Porter, Prominence and Aspect' <http://www.ntdiscourse.org/onporter-prominence-and-aspect $>$ [accessed 2 February 2011].

29 Wallace, Grammar, 511, italics added.

30 So K. L. McKay, A New Syntax of the Verb in New Testament Greek: An Aspectual Approach (SBG 5; New York: Peter Lang, 1994): 172, on Hebrews 3:14. See also, on what became known as the Porter/Fanning debate, Moises Silva, 'A Response to Fanning and Porter on Verbal Aspect' in Biblical Greek Language and Linguistics: Open Questions in Current Research, ed. Stanley Porter and D. A. Carson (Sheffield: JSOT, 1993): 77: 'In general terms, I found Porter's theoretical framework more convincing than Fanning's ... On the other hand, when it came to looking at their implementation of the principles, I had many more problems with Porter than with Fanning: time and time again I failed to see either the logic or the evidence for his interpretations.'

31 So Fanning, 'View', 215; Porter, Aspect, 269; McKay, Syntax, 172 (who translates $3: 14$, 'we have [really] come to share in Christ if we keep our initial attitude firm to the end'); Wallace, Grammar, 576, who sees the perfect in 3:14 as 'intensive'; Runge, 'On Porter'. Assessing significance is of course heavily subjective, but Porter, Handbook, 117 describes the first three as 'the major studies worth mentioning', and his footnote also mentions Wallace; the reception of Runge's most recent work, Discourse Grammar of the Greek New Testament: A Practical Introduction for Teaching and Exegesis (Peabody: Hendrickson, 2010), suggests his view deserves to join these four.

32 A further interpretation of $\gamma \varepsilon \gamma o ́ v \alpha \mu \varepsilon v$ is advocated by O'Brien, following Campbell: it 'signals intensity as an imperfective aspect with heightened proximity, and may be rendered "we are [sharers in Christ]" (O'Brien, Hebrews, 150; cf. C. R. Campbell, Basics of Verbal Aspect in Biblical Greek [Grand Rapids: Zondervan, 2008]: 110). O'Brien's view may be unlikely, but it is noteworthy that in practice, it gives the sentence the same sense as we are arguing for in this paper: perseverance 
Schreiner and Caneday, as well as Paul Ellingworth, provide an additional challenge to the Reformed interpretation of $\gamma \varepsilon \gamma o ́ v \alpha \mu \varepsilon v$. For them, the perfect in 3:14 should be interpreted in the light of the present $\dot{\varepsilon} \sigma \mu \varepsilon v$ in $3: 6 \mathrm{~b}$, and therefore, though it is apparently past in referent, it should actually be interpreted with a future orientation. As such, they agree, the two verses are essentially saying the same thing: 'We have become, and are now, partners with Christ; and we shall remain such if we hold fast to the end.' 33

The main reason for this, it seems, is that to make a past reality dependent upon a future condition, as most modern translations of 3:14 do, is 'difficult'. ${ }^{34} 3: 6 \mathrm{~b}$ does not present an interpretive problem in this regard, because the Greek present tense can carry a future sense: 'we are continuing to be his house if we hold fast', for example, would make perfect sense. ${ }^{35}$ But clearly the perfect tense in 3:14 cannot (unless, with Porter, we see it as 'timeless'). So the logic used by Ellingworth, and Schreiner and Caneday, runs: (1) a past reality cannot be predicated upon a future condition; (2) but $\gamma \in \gamma o ́ v \alpha \mu \varepsilon v$ is merely equivalent to $\varepsilon \sigma \mu \varepsilon v$, since the verses are parallel to one another, and therefore bears a present sense; (3) and because the present can bear a

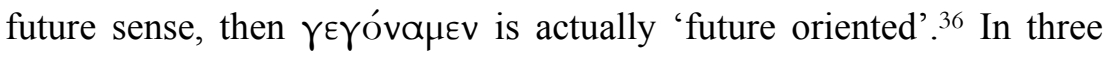
steps, then, these writers have given a perfect verb ('we have come to share') a future orientation ('we will continue to share') - without, it seems, considering that if this is what the writer meant, he has chosen a very strange way of saying it.

The problem with this analysis is not at (2), which is clearly true:

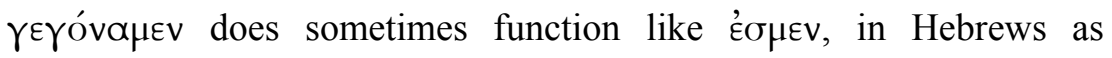
elsewhere. ${ }^{37}$ Grammatically, the problem is at (3), where a perfect is said to have 'a clear future orientation' (Schreiner and Caneday's phrase), despite no examples of this phenomenon in Koine Greek being provided (although this is more of a problem for Ellingworth than for Schreiner and Caneday, since the latter have built their interpretation

\footnotetext{
'will demonstrate that their faith is genuine', in contrast to the 'transitory or spurious faith that does not persevere' (150-52).

33 Ellingworth, Hebrews, 227; cf. Schreiner and Caneday, Race, 201.

34 This word is used in each of Ellingworth, Hebrews, 227; Schreiner and Caneday, Race, 200; and McKnight, 'Warning Passages', 57.

35 Cf. the close parallel in 1 Cor. 15:2: 'you also are being saved, if you hold fast ...'.

36 So Schreiner and Caneday, Race, 201; cf. Ellingworth, Hebrews, 227.

37 E.g. 5:11, where 'you have become dull of hearing' clearly means 'you are dull of hearing'; cf. also 5:12; 7:16, 20, 22, 23.
} 
on Porter's timeless perfect, discussed above.) As we will see in the next section, there is also a problem with (1), because it assumes a cause-to-effect relationship between the protasis and the apodosis, which there is good reason to question.

On the basis of the wording of these two verses, in fact, there is no reason to object that the main modern translations are 'difficult', or that the conclusions drawn by Bruce, Carson, Fanning and others on the

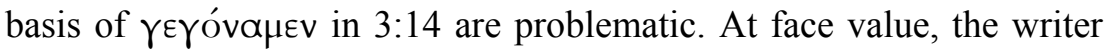
does appear to mean what (for example) K. L. McKay suggests he means: 'we have (really) come to share in Christ if we keep our initial attitude firm to the end'. ${ }^{38}$

\section{The Type of Conditional: Cause-to-effect or Evidence- to-inference}

The second major area of discussion pertaining to Hebrews 3:6b and 3:14 is the type of conditional clause they involve: cause-to-effect, or evidence-to-inference. This requires some explanation.

The most common way of reading conditional statements in Greek is to see them as describing a cause-to-effect (C-E) relationship: if C happens, then $\mathrm{E}$ will happen. In this type of conditional, the protasis is a cause, and the apodosis the effect produced by that cause. Thus Romans 7:2: 'If her husband dies' (cause) 'she is released from the law of marriage' (effect). There are numerous examples of this type of construction in the New Testament.

But by no means all conditionals express a C-E relationship. Wallace draws attention to two other types of conditionals: evidenceto-inference (E-I), and equivalence. ${ }^{39}$ In an E-I relationship, the evidence in the protasis results in an inference in the apodosis, as in Hebrews 12:8: 'If you are left without discipline ...' (evidence) 'then you are illegitimate children and not sons' (inference). In an equivalence relationship, then the protasis and the apodosis contain equivalent statements, with the emphasis falling on the apodosis: 'If you are Christ's, then you are Abraham's seed' (Galatians 3:28). It is extremely important to distinguish between these three types of

\footnotetext{
38 McKay, Syntax, 172.

39 Wallace, Grammar, 679-86. Although Wallace uses the phrase 'ground-toinference', in this paper we will use the more customary 'evidence-to-inference'.
} 
conditionals, because to confuse them could lead to a completely inverted understanding of the sentence in question:

'If she has a ring on her left hand, then she's married.' Note that the protasis is not the cause of the apodosis. In fact, it is often just the opposite: 'If she gets married, she will wear a ring on her left hand.' Thus, often, though not always, the ground-inference condition will semantically be the converse of the cause-effect condition. ${ }^{40}$

The importance of this for the interpretation of Hebrews 3:6b and 3:14 is substantial. As we have seen, the objections to Carson's reading, from McKnight, Schreiner and Caneday, Ellingworth and others, have been primarily concerned with the inherent strangeness of making a future cause produce a past effect — which is understandable - and this has resulted in some grammatically unlikely attempts to make sense of 3:14. If, however, $3: 6 \mathrm{~b}$ and 3:14 do not express a C-E but an E-I relationship, then much of this difficulty is avoided, for the verses would then involve a future piece of evidence resulting in a past (or present) inference.

Fanning, as we have already mentioned, argues in some detail that we should take 3:6b and 3:14 in the E-I sense, rather than the C-E sense. The essence of his argument is that we find a consistent pattern in the LXX and New Testament amongst third class conditionals (that is, conditionals which take the subjunctive) which resemble $3: 6 \mathrm{~b}$ and $3: 14$ :

When the protasis refers to a contextually specific event, conditionals seem to display $\mathrm{C} / \mathrm{E}$ relation (and the apodosis refers to something future from that event and caused by it) ... When the protasis refers to a contextually general situation (a customary condition or broadly characteristic action), conditionals seem to display E/I relation (and the apodosis refers to a state or condition already existing at the time of that situation and evidenced by it). ${ }^{41}$

Now, parts of this are more persuasive than others. Regarding protases, for example, it is not always straightforward to identify whether a protasis refers to a 'contextually specific event' or a 'broadly characteristic action'; it is unclear why some of Fanning's examples

40 Wallace, Grammar, 683.

41 Fanning, 'View', 211-14, quoting as examples Lev. 19:7; Job 21:6; John 19:12; Rom. 7:21; 14:23; 1 Cor. 7:39 (all C-E), and Lev. 13:51; Ezek. 14:9; John 5:31; 8:31; Rom. 2:25; 1 Cor. 13:1 (all E-I). His sample is limited to third-class conditionals where the apodosis contains the present indicative of ei $\mu$ í or the perfect indicative of any verb. 
have been identified as they have, and (to his credit) he mentions several counterexamples to the pattern in the New Testament. ${ }^{42}$ However, his observation that C-E apodoses are typically future from the protases, and that E-I apodoses are typically 'already existing at the time' of their protases, is extremely helpful, and adds support to his argument that 3:6b and 3:14 are E-I, not C-E.

One of the most interesting observations arising from this analysis, which Fanning himself does not make, is that in several of these examples, just as in Hebrews 3:14, a perfect appears in the apodosis, even though the protasis refers to a present situation. Consider:

And if the prophet is deceived and speaks a word [present evidence: subjunctive aorist active] I, the LORD, have deceived that prophet [past inference: indicative perfect active]. (Ezek. 14:9, LXX)

But if in his eyes the itch is unchanged and black hair has grown in it [present evidence: subjunctive aorist active], the itch has been healed [past inference: indicative perfect active]. (Lev. 13:37, LXX)

In both of these examples, it is clear that an E-I relationship is intended: if we observe a certain piece of evidence (a deceived prophet, black hair), then we can infer that something else has already happened (Yahweh has deceived the prophet, the itch has been healed.)

In line with this pattern, and in light of the fact that no C-E relationship in the LXX or New Testament contains a perfect active in the apodosis when the protasis speaks of a present situation, it appears best to understand Hebrews 3:14 in the same way, since the grammar and structure of the sentences are so similar. In fact, were it not for the fact that the protasis and apodosis are inverted in Hebrews 3:14 (which, if anything, makes it more likely that the normal temporal sense of the perfect is intended, since it is not distorted by the sense of the protasis), its grammatical structure would be identical to both previous examples:

For we have come to share in Christ [past inference: indicative perfect active], if indeed we hold our original confidence firm to the end [present evidence: subjunctive aorist active]. (Heb. 3:14)

This, it appears, provides a very strong grammatical basis for seeing Hebrews 3:14 as expressing an E-I relationship; on the most

42 For example, it is not clear to me why the protasis of Rom. 14:23, 'if he eats', is classed as specific, while that of Lev. 13:51, 'if the infection spreads', is general. The counterexamples he gives are 1 John 1:8, 10 (specific but E-I), and John 13:17; 1 Cor. 7:40 (general but C-E). 
straightforward reading of the grammar, the apodosis is a prior condition for the protasis, whereas in a C-E relationship, this would be inverted. The same can be said of Hebrews 3:6b, for despite using a present tense in the apodosis, it nevertheless assumes that 'we are his house' is a present state and 'if we hold fast' is a future condition; in other words, the apodosis is still a prior condition for the protasis. All of this suggests that 'holding fast' is seen by the author of Hebrews as evidence of having come to share in Christ, rather than a cause of it.

To my knowledge, the only existing scholarly critique of the evidence-to-inference interpretation of 3:6b and 3:14 has come, very briefly, from Grant Osborne. ${ }^{43}$ Osborne argues that the conditional clauses of 3:6b and 3:14 do not express prior conditions- he sees no evidence for this in the epistle - and are more likely to share the force of the 'éáv ('if') clauses in 3:7 and 3:15.44 This is rather surprising, because the evidence in the epistle is from the very two verses he is talking about: $\gamma \varepsilon \gamma o ́ v \alpha \mu \varepsilon v$ is in the perfect tense, and even $\varepsilon \sigma \mu \varepsilon v$ refers to an already existing state of affairs, as virtually all interpreters would agree. The appeal to interpret them in the same way as 3:7 and 3:15 is even more surprising, because the form of these sentences ('if you hear his voice, do not harden your hearts') is thoroughly different from that of 3:6b and 3:14 ('if you hold fast, you are his house'). Once again, we may suggest that if, as Osborne believes, $3: 6 \mathrm{~b}$ and 3:14 are intended to explain that 'only if they persevere will they partake of Christ', just as the Israelites 'would only enter God's rest if they heard (and obeyed) God's voice', then the writer has expressed it very strangely-not least by making it clear that, unlike entering God's rest, being God's house

43 Very brief mentions of the argument as presented by Fanning appear in Gareth Cockerill, 'Wesleyan Arminian Response' in Bateman, Four Views; Randall Gleason, 'Moderate Reformed Response' in Bateman, Four Views; and Thomas Schreiner, Run to Win the Prize (Nottingham: Apollos, 2009). Cockerill only mentions 3:14 in a footnote, and is content to dismiss Fanning's argument by quoting Ellingworth and Weiss; Gleason concedes the E-I argument, but contends that it cannot thereby serve as an interpretive paradigm for the whole letter; and Schreiner argues that 3:6b and 3:14 must be C-E because the other warnings in Hebrews are. These brief points will be engaged with further below, but none of these responses engage with the grammatical arguments for reading 3:6b and 3:14 as E-I conditions.

44 Osborne, 'Response', 231. Elsewhere, Osborne appears not to have quite understood what Reformed writers have typically said, characterising Bruce and Carson as proponents of a C-E relationship, and reads the cause as 'being his house' and the effect as 'holding on' (224), which is clearly not what either argue (see Bruce, Hebrews, 94; Carson, 'Reflections', 267). Carson, in particular, is very clear that perseverance is the 'evidence' of partnership with Christ; see Carson, Fallacies, 85. 
and partaking of Christ were things which were true of the readers already. ${ }^{45}$

On balance, then, the evidence-to-inference reading of $3: 6 b$ and $3: 14$ appears the most compelling one, on grammatical grounds. Consequently, it seems preferable, in the absence of any significant challenge to this interpretation from within the verses themselves, to interpret them in the way that Fanning, Carson, Guthrie and Bruce do, rather than in the way McKnight, Schreiner and Caneday, Ellingworth and Osborne do, at least until a good reason not to is presented.

It now remains for us to look finally at the wider context, to see if the letter as a whole makes such an interpretation implausible.

\section{The Wider Context}

Context normally comes first, of course, and rightly so. However, so many scholars have, on the grounds of context, either produced grammatically unlikely readings of Hebrews 3:6b and 3:14, or ignored both the Reformed interpretation and the evidence-to-inference view altogether, that in this case, it has been helpful to leave the wider context of the letter until the end. ${ }^{46}$ Now, though, we must ask how the interpretation of these verses we have advanced so far coheres with the rest of the letter.

The immediate context of Hebrews 3 is easily summarised. In 3:1$6 \mathrm{a}$, the writer addresses the readers as 'holy brothers' who 'share in a heavenly calling' (which, if it were not clear already, identifies his intended readers as Christian believers), and then urges them to consider a comparison between Jesus and Moses, showing that whereas Moses was a servant in God's house, Jesus was a son in God's house, and was therefore worthy of much greater glory. In 3:6b, he then uses 'house' as one of several catchwords in the letter, to transition from this comparison to the warning he is about to begin - and we are his house, he says, if we hold fast our confidence and our boasting in our hope.

45 Osborne, 'Response', 231.

46 For the former, see Schreiner and Caneday, Race; Ellingworth, Hebrews; McKnight, 'Warning Passages'; Osborne, 'Response'; for the latter, see Spicq, Hébreux; Attridge, Hebrews; Lane, Hebrews; Koester, Hebrews. 
This is followed by the lengthy quotation from Psalm 95 (3:7-11). For the writer, the generation who left Egypt serve as a salutary warning for his readers, in that they, like the readers, were a pilgrim people in between redemption and inheritance, but hardened their hearts and rebelled against God, resulting in a failure to enter God's rest. ${ }^{47}$ So he warns them to guard against an unbelieving heart and sin's deceitfulness, by encouraging one another daily (3:12-13), because we have come to share in Christ if only we hold fast our confidence (3:14), and because the Israelites were unable to enter God's rest, despite their redemption from Egypt, because of unbelief (3:15-19). This approach continues well into chapter 4 , where the whole theme of entering rest by believing is explored more fully.

The context of chapter 3 is surely compatible with both major interpretations of $3: 6 \mathrm{~b}$ and $3: 14$. In the Reformed reading, $3: 6 \mathrm{~b}$ and $3: 14$ serve to highlight the fact that 'there is a transitory or spurious faith that does not persevere', and to urge the readers to persevere in order to 'demonstrate that their faith is genuine'. ${ }^{48}$ In the majority interpretation, on the other hand, they contain additional implicit warnings: if you persevere in faith, then you will remain the house of God and partners with Christ, but (implicitly, as a result of the intensified conditional éávтrep) if you do not, then you will not. ${ }^{49}$ Either of these interpretations, in fact, could fit quite naturally within the chapter-neither can be ruled out from the immediate context, and both have been argued for by competent scholars. As such, Hebrews 3 on its own does not particularly help clarify which of these two things the writer intended.

It therefore remains to consider how the interpretation of $3: 6 \mathrm{~b}$ and 3:14 fits together with the other warning passages. Scholars have tended to go in one of two different directions at this point. At one extreme, there are Reformed writers like D. A. Carson, Wayne Grudem, Buist Fanning and others, who make these two verses paradigmatic for all the warnings, and proceed to argue that despite appearances, the rest of the letter is not addressing its dire admonitions towards true believers, but those who appear to be believers but

\footnotetext{
47 The classic statement remains that of Käsemann, The Wandering People of God (Minneapolis: Augsburg, 1984).

48 O'Brien, Hebrews, 150, 152.

49 Thus Ellingworth, Hebrews, 227; Weiss, Hebräer, 250.
} 
demonstrate by their apostasy that they are not. ${ }^{50}$ At the other extreme, there are those who do the exact opposite: the warnings in Hebrews are addressed to genuine believers, not phenomenological ones, and therefore, despite appearances, Hebrews 3:6b and 3:14 must be causeto-effect conditionals with a future orientation in the apodosis. We have already considered the latter approach in some detail, and found it problematic from a grammatical point of view, but the former also faces grave difficulty.

The main reason for this is that the descriptions of the people to whom the warnings in Hebrews are addressed are so comprehensively Christian. ${ }^{51}$ For a start, the author directly applies four of the five major warning passages to himself $(2: 1-4 ; 4: 1 ; 10: 26 ; 12: 25-29)$. Not only that, but as has often been rehearsed, the recipients of the warnings are described as 'brothers' (3:12), 'enlightened', 'partakers of the Holy Spirit' (6:4), as those who have 'tasted the heavenly gift' and 'the goodness of the word of God and the powers of the age to come' (6:45), who have 'received knowledge of the truth' (10:26), been 'sanctified' by the blood of the covenant, and then 'outraged the Spirit of grace' (10:29). Frankly, it is hard to think of a more complete statement of Christian experience in the New Testament, and this makes the Reformed interpretation of the warnings, particularly 6:4-6 and 10:26-31, very problematic. ${ }^{52}$ When read together, it seems clear that in the warning passages, the writer is exhorting the Christian readers to continue in faith-which in Hebrews, as Grässer has conclusively shown, is an ongoing, persevering confidence in the

50 So Carson, 'Reflections'; Wayne Grudem, 'Perseverance of the Saints: A Case Study from the Warning Passages in Hebrews' in Schreiner and Ware, Still Sovereign, 133-82; Fanning, 'View'.

51 The literature is voluminous, and a comprehensive review of the issues is impossible here, but particularly helpful statements of the case made here are found in Attridge, Hebrews, 166-73, 292-95; McKnight, 'Warning Passages'; Lane, Hebrews, 290-93; deSilva , Hebrews, 221-25, 343-350; Koester, Hebrews, 313-14.

52 So Marshall, Kept, 142-45. The fullest attempts to argue that the descriptions in Hebrews do not apply to true believers are probably Nicole, 'Comments'; Grudem, 'Perseverance'. For compelling responses, see McKnight, 'Warning Passages'; Schreiner and Caneday, Race, 195-99; cf. also Osborne, 'A Classical Arminian View' in Bateman, Four Views, 112: 'it is nearly impossible to relegate these descriptions to non-Christians. If this passage were found in Romans 8 , we would all hail it as the greatest description of Christian blessings in the entire Bible.' It is noteworthy that Fanning, who argues for a Reformed interpretation, admits that 'a straightforward reading of these descriptions leads us to understand them to refer to full and genuine Christian experience' ('View', 180). 
divine promise, rather than a once-for-all moment of belief- to inherit a salvation that is primarily future $(1: 14 ; 9: 28) .{ }^{53}$

The question, then, is whether the author's strong warnings to believers about 'falling away' are incompatible with the interpretation of 3:6b and 3:14 that we have advocated so far in this paper. For a number of scholars, as we have seen, they clearly are; for Schreiner, Osborne and presumably McKnight, the very fact that the warning passages are intended to prevent believers from falling away rules out the evidence-to-inference interpretation of $3: 6 \mathrm{~b}$ and 3:14 altogether. ${ }^{54}$ What possible use is it to warn people to persevere in faith, if you believe that those who are truly partakers of Christ will hold fast their assurance to the end? Would this not relegate the warnings to being merely hypothetical?

Not necessarily. The hypothetical argument has been made, of course, but it has been rightly criticised for its evasion of the plain meaning of the passage, for its distortion of the views of other scholars, and for turning simple conditionals into contrary-to-fact suppositions. ${ }^{55}$ But this is not the only way of combining the grammatically likely reading of $3: 6 \mathrm{~b}$ and $3: 14$ with the majority interpretation of the warnings as a whole. The alternative, which in our view has far more to commend it, is to see the warnings as the author of Hebrews appears to: as a means of preserving God's people in faith to the end. This causes him both to urge perseverance and warn against apostasy in the strongest possible terms, and to have confidence that the readers will heed his warnings if they have in fact become partners with Christ, since he sees his warnings are God's way of preventing the readers from apostasy.

The main objection to reading $3: 6 \mathrm{~b}$ and $3: 14$ as we have suggested in this paper, it appears, is the assumption that it is logically

53 See Erich Grässer, Der Glaube im Hebräerbrief (Marburg: Elwert, 1965); cf. Grässer, Hebräer, 373. For salvation as primarily future in Hebrews, see deSilva, Hebrews, 221; O'Brien, Hebrews, 79.

54 So Thomas Schreiner, Run to Win the Prize (Nottingham: IVP, 2009): 96; Osborne, 'Response', 231. I say 'presumably' of McKnight because he does not respond specifically to the evidence-to-inference interpretation, but his paper suggests he would respond in the same way as Schreiner and Osborne at this point ('Warning Passages', 24, 57.)

55 So Thomas Hewitt, The Epistle to the Hebrews: An Introduction and Commentary (TNTC; Grand Rapids: Eerdmans, 1960): 111; Homer Kent, The Epistle to the Hebrews: A Commentary (Grand Rapids: Baker, 1972): 111-13. For a brief but decisive critique, see Marshall, Kept, 146; Schreiner and Caneday, Race, 36-37. 
incompatible for a writer to (a) believe that someone will persevere in faith, at the same time as (b) warning them against falling away. ${ }^{56} \mathrm{Put}$ more broadly, it assumes the incoherence of (a) being confident of safety while also (b) warning of danger. But a moment's reflection shows that this assumption is clearly flawed, for the simple reason that one may be confident of someone else's safety because one has warned them effectively of danger; the roadside 'danger' sign analogy is perhaps overused, but apposite. ${ }^{57}$ This, we may suggest, is why the writer says in 6:9 that 'though we speak like this, brothers, we are confident of better things in your case'. The warnings, the author believes, will prevent the readers from falling away. This is not incoherent at all, even if it does indicate a more subtle view of the interaction between divine and human agency than that with which the author of Hebrews has normally been credited.

It is not obviously incoherent, for example, for Paul to argue in Romans that (a) all who are foreknown, called and justified will be glorified, and yet that (b) glorification is conditional upon persevering in good works, and suffering with Christ. ${ }^{58}$ Nor is it logically incompatible for him, in writing 1 Corinthians, to (a) affirm that God will keep the saints strong to the end and present them blameless at the eschaton, and yet (b) warn believers away from desiring evil and being destroyed, from being disinherited from the kingdom of God for unrighteousness, and from being disqualified from the prize. ${ }^{59}$ Ardel

56 That this makes no sense is agreed by scholars on opposite ends of the spectrum; Marshall calls such warnings 'empty' (Kept, 146), and Grudem calls them 'useless' ('Perseverance', 152). Cf. Nicole, 'Comments', 356: 'When there is an insuperable barrier there is no need to give warning concerning dangers on the other side!' This invites the question, of course: but what if the warning itself is the barrier?

57 See G. C. Berkouwer, Faith and Perseverance (Grand Rapids: Eerdmans, 1958; tr. Robert Knudsen); Schreiner and Caneday, Race. This view finds its most eloquent expression in the sermon of the Baptist preacher Charles Spurgeon on Heb. 6:4-6: 'God preserves his children from falling away; but he keeps them by the use of means ... There is a deep precipice: what is the best way to keep anyone from going down there? Why, to tell him that if he did he would inevitably be dashed to pieces' (The New Park Street Pulpit <www.spurgeon.org/sermons/ 0075.htm> [accessed 16 February 2011]).

58 Rom. 8:28-30; 2:6-11;8:17. Each of these passages is, of course, the subject of much debate, but this does not change the fact that most scholars have not regarded them as logically incompatible with each other.

591 Cor. $1: 8-9$; 10:1-13; 6:9-11; 9:24-27. Again, there is controversy here, but it is clearly possible to see Paul as holding both (a) and (b) together; for one way of reading the letter this way, see the comments of Gordon Fee, The First Epistle to the Corinthians (NICNT; Grand Rapids: Eerdmans, 1987): esp. 43-44, 248, 462. 
Caneday's example of the shipwreck in Acts 27 makes this point clearer still: Luke records both (a) Paul's confidence that the entire ship would be saved - based on an angelic visitation, no less! - and yet, soon afterwards, (b) his urgent warning that if the crew left the ship, the company would not be saved, which was the means by which the sailors' lives were preserved. ${ }^{60}$ In each of these cases (and others could be cited), confidence of perseverance and strong warnings coexist. It therefore seems unreasonable to rule out the interpretation of $3: 6 \mathrm{~b}$ and $3: 14$ we have argued for on the basis that it is incompatible with the wider context of Hebrews.

\section{Conclusion}

With this paper, we enter uncharted waters. ${ }^{61}$ Scholarship has generally concluded one of two things about Hebrews 3:6b and 3:14 in relation to the rest of the warnings: either we have two cause-to-effect conditionals alongside warnings to true believers, or we have two evidence-to-inference conditionals alongside warnings to 'false', 'spurious' or 'transitory' believers. But in this paper, we have argued that the former does not fit well with the grammar and logic of $3: 6 \mathrm{~b}$ and 3:14, and the latter does not fit well with the context and language of the other warnings. Therefore, we have concluded, we are probably dealing with two evidence-to-inference conditionals alongside warnings to true believers: holding fast one's confidence is evidence of partnering with Christ, and persevering in faith is essential if one is to inherit salvation. The warnings in Hebrews, then, should be treated like many other warnings in the New Testament-as genuine admonitions, whose purpose is to exhort the readers to persevere, and which serve to ensure this happens by highlighting the danger of falling away. And $3: 6 \mathrm{~b}$ and $3: 14$, read this way, mean exactly what the major translations make it look like they mean - that we have become, and are now, God's house and Christ's partners if indeed we hold fast our confidence.

60 Acts 27:21-26, 31-32; so Schreiner and Caneday, Race, 209-11.

61 As far as I am aware, no scholarly work has yet argued for the majority view of the warnings alongside the Reformed view of 3:6b and 3:14; however, the sermons of Charles Spurgeon (cited above) handle the relevant material in exactly this way. 
